\title{
Improving rural livelihoods as a "moving target": trajectories of change in smallholder farming systems of Western Kenya
}

\author{
Diego Valbuena · Jeroen C. J. Groot • \\ John Mukalama • Bruno Gérard • Pablo Tittonell
}

Received: 2 December 2013/ Accepted: 25 September 2014/Published online: 21 October 2014

(c) The Author(s) 2014. This article is published with open access at Springerlink.com

\begin{abstract}
Understanding the diversity of current states, life cycles and past trajectories of households and agroecosystems is essential to contextualise the co-design of more sustainable agroecosystems. The objective of this paper was to document and analyse current states, trajectories of changes and their major drivers of households in a highly populated maize-based agroecosystem of Western Kenya. In 2013, we revisited 20 rural households that were surveyed, analysed and categorised 10 years ago (2003) in order to describe major changes in livelihood strategies, land use and soil fertility status. The household-level analysis was complemented with the analysis of secondary data on changes in drivers at the national level for the study period. The diachronic study showed a close association between drivers such as market and transport development, and the structure of rural households in terms of demographic shifts, land and labour exchanges, increased costs of agricultural inputs and better connectivity to markets. Between 2003 and 2013, the surveyed households
\end{abstract}

Editor: Marc J. Metzger.

D. Valbuena $(\varangle)$ · J. C. J. Groot · P. Tittonell

Farming Systems Ecology Group, Wageningen University,

Wageningen, The Netherlands

e-mail: diego.valbuena@wur.nl

D. Valbuena

International Center for Tropical Agriculture (CIAT), Managua, Nicaragua

\section{J. Mukalama}

International Center for Tropical Agriculture (CIAT), Nairobi, Kenya

B. Gérard

International Maize and Wheat Improvement Center (CIMMYT), Texcoco, Mexico experienced an increase in non-agricultural income by $30 \%$; intensity of land cultivation by $60 \%$; use of hybrid maize seeds by $35 \%$; and of synthetic fertilisers by almost $50 \%$. Local households increase their number of crossbred livestock in detriment of local breeds and used less manure to fertilise their soils. In contrast, there were few changes in terms of food self-sufficiency (around 9 months per year) and in soil conditions (soil fertility was already poor in 2003). In terms of livelihood strategies, betterendowed households tended to diversify and acquire land that enabled them to adapt and benefit from the major changes observed in external drivers. In contrast, more vulnerable households sold labour and land to cope with such changes, remaining in a poverty trap. Households combine and explore diverse strategies to act, cope and adapt to fast-changing local and regional drivers. Policy or development programmes need to account for such diversity and dynamics to support the co-development of more adaptive and sustainable smallholder agroecosystems.

Keywords Social and environmental change - Adaptive capacity · Eastern Africa · Household diversity · Adaptive capacity $\cdot$ Agroecosystems $\cdot$ Drivers of change

\section{Introduction}

The current configuration, performance and plausible future pathways of a particular agroecosystem are largely determined by the past dynamics and interactions between its intrinsic properties and external drivers (i.e. external factors influencing these intrinsic properties) such as climate, local institutions, population dynamics and markets (Zimmerer 2007, 2013; Raut et al. 2011). Agroecosystems are social-ecological systems managed by humans to 
provide goods and services, particularly the production of food, feed, and fibre for human needs (Conway 1987; Becker and Jahn 2001). Their dynamics and long-term trajectories in the face of changing contexts express their responses to gradual changes and sudden disturbances, which can be characterised in terms of vulnerability, resilience, adaptive capacity and overall sustainability (social, environmental and economy). At lower hierarchical levels, rural households that are part of evolving agroecosystems combine different strategies to cope or adapt to such changes in their context and their own life cycle dynamics (e.g. Speelman et al. 2014). While some households have to use some strategies to cope with changes by hanging in, others can use other strategies to support the adaptation by the stepping up or out based on agricultural production and non-farm income, respectively (Dorward et al. 2009). Surprising, or rather unexpected agroecosystem dynamics and patterns can emerge from the complex interaction between system management and the various external drivers operating at multiple levels/scales.

Understanding the diversity of current states and past trajectories of households and agroecosystems can generate relevant knowledge to better contextualise and support discussions regarding the co-development, adaptation, integration and adoption of promising agricultural innovations and diversification strategies, and their potential impacts on the livelihoods of smallholder farmers (Scoones and Wolmer 2000; Ryschawy et al. 2013; Zimmerer 2013). In particular, improved integration and management of ecological processes to enhance agricultural production while reducing dependence on external inputs in the face of climatic variability require strengthening the adaptive capacity of households and local institutions as lead actors of agroecosystems (Pretty 1997, 2008; Reardon et al. 1999; Keating et al. 2010).

Changes in biophysical and socio-economic drivers may promote or limit changes in the use of land (Lambin et al. 2006; Rindfuss et al. 2008) and access to other resources (e.g. water, nutrients, labour, capital), influencing positively or negatively rural livelihoods, farming systems (Wilson 2008; Enfors 2013; Tittonell and Giller 2013), and overall sustainability (Tarawali et al. 2011). The understanding of trajectories of households and agroecosystems as affected by changes in drivers and interactions among drivers operating at different spatial and organisational levels can shed light on the ecological and social underpinning of their adaptive capacity and resilience (Geels and Schot 2007; Tittonell 2013).

In Western Kenya, one of the most densely populated rural areas in the world, households combine diverse livelihood strategies, management practices and commodities to react to or anticipate processes and changes in agroecological (e.g. climate) and socio-economic (e.g. population dynamics and markets) drivers. Household decisions, their life cycle and changes in external drivers influence their current performance and potential future pathways, as has been documented in a number of studies (e.g. Conelly and Chaiken 2000; Crowley and Carter 2000; Tittonell et al. 2005a, b; Jayne and Muyanga 2012). Most of these studies concurred in diagnosing severe soil degradation and overall land fragmentation as a consequence of high population pressure on the natural resource base. Yet, the dynamics of market development, trends in the national economy, and the increased rural-urban connectivity in Kenya over the last decade may have promoted changes in livelihood strategies that can only be captured through longitudinal studies. Our objective was to document and understand such trajectories to better contextualise opportunities for sustainable natural resource management pathways in the highly populated maizebased agroecosystems of Western Kenya. We revisited rural households from the area that were surveyed, analysed and categorised 10 years ago to document major changes in livelihood strategies, land use and soil fertility status. We combined the analysis of secondary data on national drivers together with the analysis of field data collected in 2003 and 2013.

\section{Methods}

\section{Study area}

The study area was located in Shinyalu, a Constituency of the Kakamega District in Western Kenya (Fig. 1). Its agroecosystems host diverse smallholder households farming between 0.5 and 2 ha of land, where they combine crop, livestock and tree production. Although agriculture plays a major role, households have combined different

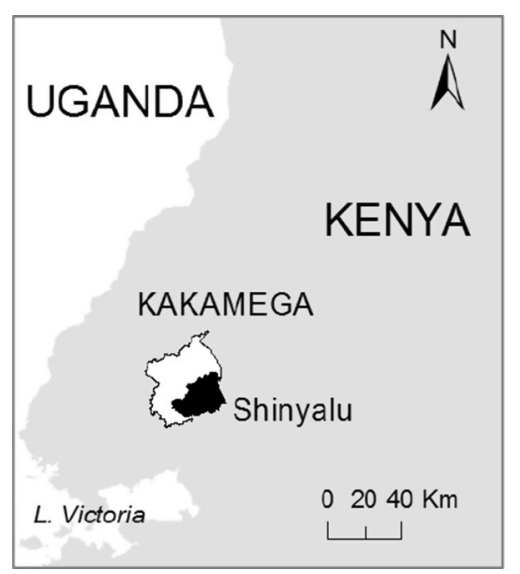

Fig. 1 Location of Shinyalu constituency and Kakamega District 
strategies to achieve their livelihoods including migration and income diversification (Crowley and Carter 2000; Lay et al. 2008).

The study area is sub-humid, receiving on average between 1,500 and 2,500 $\mathrm{mm}$ of rain distributed in two rainy periods, the long (March-July) and short (August-November) rains, which allow two cropping seasons per year. The area is characterised by a rolling landscape with a combination of flat and undulating slopes dominated by soils of the orders: Nitisols, Ferralsols and Acrisols (Jaetzold et al. 2007). Most soils in the area are degraded as a result of pedo-climatic conditions combined with long-term cultivation, insufficient use of organic matter or other nutrient inputs, and erosion (Tittonell et al. 2005a, b; Jaetzold et al. 2007).

Agricultural expansion and urbanisation have considerably reduced the areas of land under communal usufruct (e.g. communal grazing) in the study region. Agricultural intensification has facilitated a continuous agricultural production and population growth, while reported average farm sizes for the whole population continue to decline and limit the practice of fallow or crop rotation as means to manage soil fertility (Nambiro 2008). The agroecosystem is dominated by the intercropping of maize (Zea mays L.) and common beans (Phaseolus vulgaris L.), combined with many different food, feed and cash crops and trees (Crowley and Carter 2000; Tittonell et al. 2010). However, many households do not cover their food demands, being net buyers of maize. Also, after communal grazing areas became scarce some decades ago, livestock herds have remained small with a combination of cross-bred and indigenous cattle, goats, sheep, pigs and poultry with changes in feeding practices (Crowley and Carter 2000).

\section{Data collection and analysis}

The analysis of trajectories was based on the collection and comparison of data and indicators on drivers, livelihoods and soils in 2003 and 2013. Indicators on the major changes in biophysical and socio-economic drivers were collected by gathering secondary data covering that period to better contextualise changes in livelihoods and farming systems. The aim was to provide an overview on the major dynamics rather than an in-depth analysis of drivers. The search focussed on national and global datasets of different organisations including KNBS or the Kenya National Bureau of Statistics (http://knbs.or.ke/), FAO (http://fao stat.fao.org/), World Bank (http://data.worldbank.org/) and United Nations (http://unstats.un.org). District population data for 2003 and 2013 are an extrapolation of the data of the national census of 1999 and 2009 (KNBS 2000, 2010). This extrapolation was done based on the annual growth rates that were calculated by comparing the District population of 1989 and 1999 (i.e. $2.5 \%$ ), and 1999 and 2009 (i.e. $2.7 \%$ ).

Household data on family structure, life cycle, crop and livestock production, and income were collected from the same households in two different years: 2003 and 2013 (see Table 3 in "Appendix"). The methods used in both years are described in detail in Tittonell et al. (2005a and b). In 2003, 20 households were selected after having categorised the diversity of local households into a farm typology based on resource endowment levels out of survey data. Semi-structured questionnaires and participatory mapping tools were used to collect farm management data to better understand diversity of crop and livestock management practices, resource flows, farm productivity and market prices for agricultural inputs and outputs (for further details see Tittonell et al. 2008). In 2013, these households were revisited and similar though adapted questionnaires were used to collect key indicators on livelihoods and farming systems, as well as storylines on the past trajectories and potential future strategies. In total, 19 interviews were conducted because we were not able to contact one of the households. The values of the collected household data were compared for all the households to check statistical differences between years by using the Wilcoxon Matched-Pair Signed-Rank, a nonparametric test to evaluate differences between repeated measurements of the same sample.

A sub-sample of five representative households of the typology was selected to conduct a detailed system characterisation including quantitative data on resource allocation, and farm biophysical and socio-economic efficiencies, in exactly the same way as reported in Tittonell et al. (2005a and b). Additionally, discussions with key informants were conducted to collect current prices of main agricultural inputs and understand major changes in local markets and general land use changes in the region. Although prices of agricultural products are highly variable in the study area (Tittonell et al. 2007), major changes can be still an indicator of relative variations in agricultural costs. Prices of agricultural inputs for both years were divided by the highest retailer's price of maize for food for each year in order to compare the relative value of agricultural products between years accounting for other factors (e.g. devaluation, inflation).

Soils were re-sampled and analysed for each field of the sub-sample of farms used for the detailed study to quantify potential changes in soil carbon and nutrient concentrations. Samples were taken from the first $15 \mathrm{~cm}$ of the soil profile, making a composite sample of 5 sub-samples per plot (Tittonell et al. 2005a and b). Standard analytical procedures for tropical soils (Anderson and Ingram 1993) were followed to analyse the composite samples for texture, $\mathrm{pH}$, organic carbon (OC), total $\mathrm{N}$ and extractable $\mathrm{P}$ 
(Olsen). Results from nutrient content of 2003 and 2013 were compared using descriptive analysis.

\section{Results and discussions}

Major changes in drivers and the agrarian sector

During the last decade, substantial changes occurred in both the bio-physical and socio-economic contexts affecting the agrarian sector in Kenya, which could potentially affect the dynamics of livelihoods and the agroecosystem in the study area. In the whole of Kenya, annual population growth remained constant at around $2.6 \%$ with a total increase of $\sim 10$ million people, from 33.8 million in 2003 to almost 43.9 million in 2013 (UN 2011). The increase in population was relatively larger in the cities than in rural areas caused by a close interaction between population growth and urban migration, as the percentage of urban dwellers increased from $21 \%$ to almost $24 \%$ of the total population by 2011 (UN 2011). Following demographic trends, total enrolment in secondary education doubled between 2003 and 2011, reaching almost 1.8 million, while the number of students in primary education increased from 7.2 to 9.9 million (KNBS 2012). Cereal consumption for the whole country also increased between 2003 and 2011, but no change in yields was observed. During this period, the total production increased due to an expansion of the cultivated area from 2.1 to more than 2.5 million ha, while average yields remained unchanged at an average of $1.5 \mathrm{Mg}$ per ha (FAOSTATS 2012). During the same period, the increasing but oscillating trend of cereal imports continued with a peak of 2.7 million tons in 2009 (Fig. 2), while the total value of imported $\mathrm{N}$ and $\mathrm{P}$ fertilizers quadrupled from 14 to 58 million US dollars in 2010 (FAOSTATS 2012). Livestock production also increased in the last decade, reflected in a rise in the number of animals purchased in licenced abattoirs between 2005 and 2011: 18, 38 and $24 \%$ more cattle, sheep/goats and pigs were purchased, respectively (KNBS 2012).

The total GDP of Kenya increased on average $4.6 \%$ per year in spite of the economic slowdown of 2008 (1.5\%) after the problematic elections the year before (World Bank 2013). In contrast, the relative value of agricultural production in the GDP further decreased, falling from 29 to $23 \%$ between 2003 and 2011 (World Bank 2013). The national currency (Kenyan Shilling or KES) experienced an average annual devaluation rate of $9.5 \%$. Related to this, there were increases of almost $65 \%$ in maize prices and $124 \%$ in auctioned tea prices between 2005 and 2011 (KNBS 2012). The official annual remittances to the country from abroad increased by $\sim 350 \%$ between 2004 and 2012, reaching $\sim 1.2$ billion US dollars in 2012

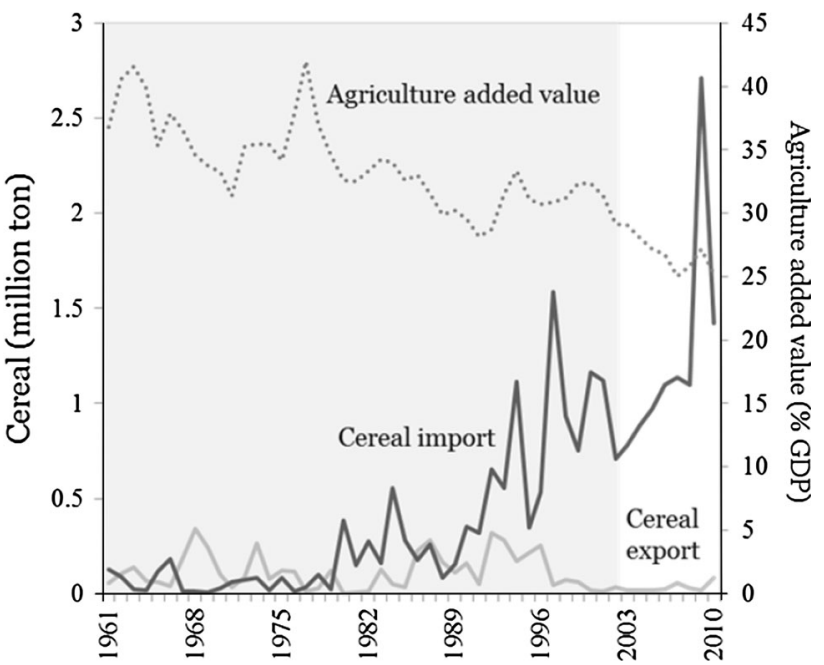

Fig. 2 Major trends in export and import of cereals and shared value of agriculture in the GDP of Kenya between 1961 and 2011. Shaded area covers the years before the period of this study. Source: FAOSTATS

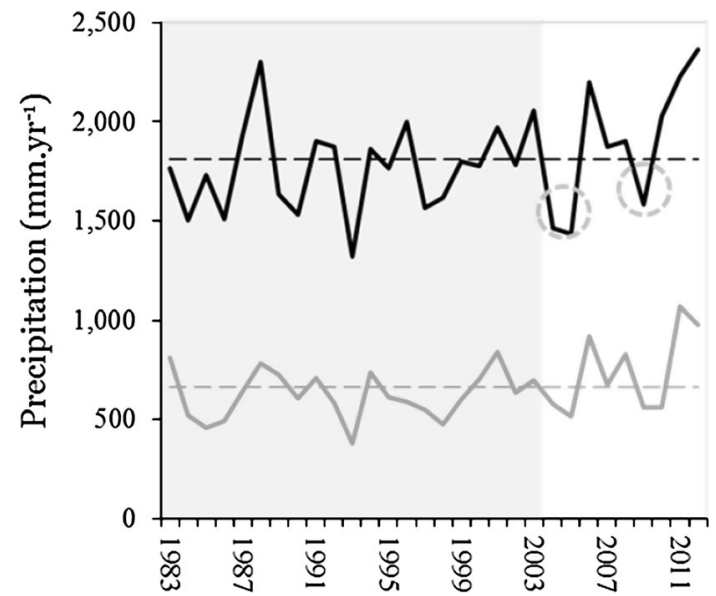

Fig. 3 Total annual precipitation (black solid line) and precipitation short rains between August and November (grey solid line) in the study area between 1983 and 2012 and their averages (dotted black and grey line, respectively). Dotted circles indicate drought periods during 2003-2013. Shaded area covers the years before the period of this study. Source: NOAA (Novella and Thiaw 2013)

(source: http://www.centralbank.go.ke). The use of mobile phones reached $60 \%$ of the population by 2010 , costumers of mobile phone-based money transfer (M-PESA) jumped to 14 million people by 2011 with a major mobile phone provider (Safaricom 2011). Furthermore, the number of registered motorbikes grew exponentially from less than 5 thousand in 2005 to almost 1.4 million in 2011 (WHO 2012).

Parallel to these major trends at national level, similar changes were observed at the district level. In Kakamega population grew from $\sim 650.000$ to $\sim 850.000$ persons 
between 2003 and 2013 reaching a population density of 592 persons per $\mathrm{km}^{2}$. The city of Kakamega had a similar growth rate with the population going from $\sim 82.000$ to $\sim 104.000$ people in the same period. People at school increased from 39 to $44 \%$ of the population between 1999 and 2009. Currently, besides the 800,000 chickens kept by local farmers, cattle is the dominant livestock species in the district with more than 200,000 heads of cattle, compared with 35,000 sheep, 30,000 goats and 15,500 pigs (KNBS 2010).

Finally, Kenya experienced climatic extremes during this period, with two major drought periods disrupting agricultural production and food prices in 2004-2005 (Kandij 2006) and 2008-2011 in the entire country (Republic of Kenya 2012), including the study area (Fig. 3). Rainfall data recorded at different locations in Western Kenya from 1958 show a trend towards monomodality, characterised by a shortening of the dry spell in between the long and short rains seasons and a concentration of rainfall during the short rains season in the months of August and September in the last decade (Tittonell 2008).

Household and farming system dynamics

Households changed and acted upon the significant contextual changes described above. We observed a diversity of strategies deployed by households to assure their livelihoods (Fig. 4), similar to the heterogeneity in intensification trajectories described by Crowley and Carter (2000). Through the new household survey and interviews with key informants, we identified four major changes experienced by local households that were partly internal to the household life cycle and structure and partly external drivers affecting the context of the agroecosystem. These were, namely changes in: (i) household composition, (ii) land and labour exchanges, (iii) prices of inputs and products and (iv) access to markets and infrastructure. The population and economic changes at national and district level ("Major changes in drivers and the agrarian sector" section) influenced in particular the external drivers affecting the households.

(i) Changes in household composition: Although the average number of household members increased (Table 1), this increase was not significant because some households increased, while others decreased, in family size. Changes in the life cycle and family structure of the rural households resulted from changes in the number of children per household, from new marriages, illnesses and death. In 2013, $42 \%$ of the household heads had changed compared with 2003, mainly as a consequence of the dead of the previous one. From the 19 households, four ceased to exist in the study area in 2013: for three of them the household head died and their farms were given to relatives who already had farms, while the remaining one sold the land to neighbours and migrated to another region. Three of these four households exhibited low levels of resource endowment already in 2003. On the other hand, more than ten new households emerged by inherit some of the land surveyed in 2003.

(ii) Changes in land and labour exchange: Although most farmers changed the amount and combination of key resources they used, only few of them have strongly increased their access to land, livestock and financial

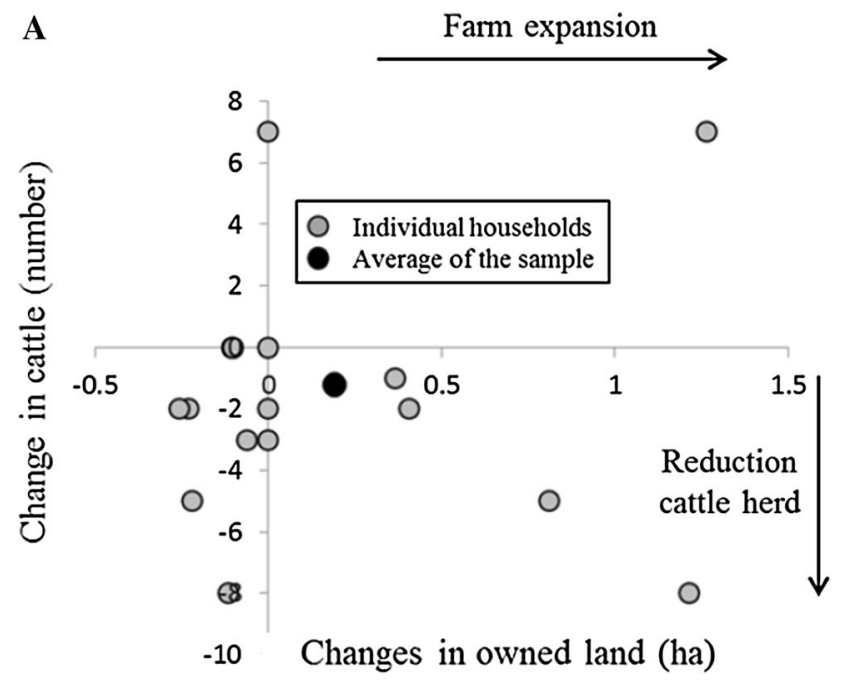

Fig. 4 Changes of household structural indicators between 2003 and 2013. a Proportional change in owned land and number of cattle. b Proportional change in annual area of cultivated land and share of

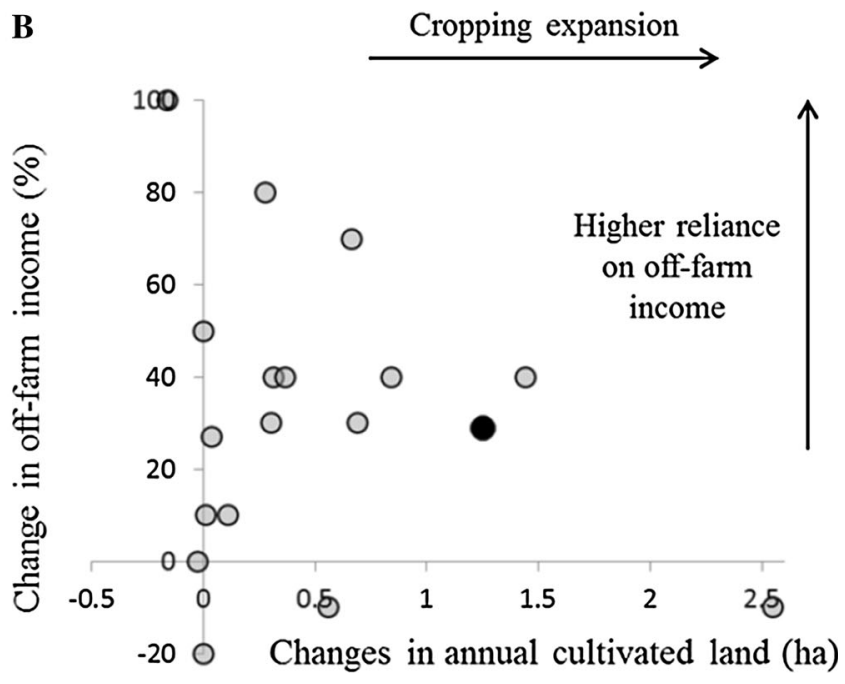

total household income obtained through off-farm activities. Arrows show the direction of potential changes. Data from 2003 were previously published in Tittonell et al. (2005) 
Table 1 Average values of major agricultural indicators of 15 households in 2003 and 2013

\begin{tabular}{|c|c|c|c|c|}
\hline Indicator & Unit & $2003^{\mathrm{a}}$ & 2013 & $\begin{array}{l}\text { Difference } \\
(\%)\end{array}$ \\
\hline \multicolumn{5}{|l|}{ General } \\
\hline Family size & {$\left[\mathrm{pp}^{\mathrm{b}} / \mathrm{hh}\right]^{\mathrm{c}}$} & $7.1 \pm 3.0$ & $7.5 \pm 5.7$ & 5 \\
\hline $\begin{array}{l}\text { Maize self- } \\
\text { sufficiency }\end{array}$ & {$[\mathrm{kg} / \mathrm{pp}]$} & $9.3 \pm 2.0$ & $8.9 \pm 2.9$ & -4 \\
\hline \multicolumn{5}{|l|}{ Crop production } \\
\hline Farm size & [ha/hh] & $0.50 \pm 0.4$ & $0.69 \pm 0.7$ & 38 \\
\hline $\begin{array}{l}\text { Annual } \\
\text { cultivated land }\end{array}$ & [ha/hh] & $0.43 \pm 0.2$ & $0.96 \pm 0.8$ & 124 \\
\hline $\begin{array}{l}\text { Frequency of } \\
\text { cultivation }\end{array}$ & {$[\%]$} & $101 \pm 39$ & $157 \pm 44$ & 56 \\
\hline $\begin{array}{l}\text { Maize hybrid } \\
\text { use }\end{array}$ & {$[\% \mathrm{hh}]$} & 40 & 80 & 40 \\
\hline Fertilizer use $^{\mathrm{d}}$ & {$[\% \mathrm{hh}]$} & 27 & 80 & 53 \\
\hline Manure use & {$[\% \mathrm{hh}]$} & 82 & 65 & -17 \\
\hline \multicolumn{5}{|c|}{ Livestock production } \\
\hline Cattle & {$[\% \mathrm{hh}]$} & 93 & 40 & -53 \\
\hline $\begin{array}{l}\text { Cross } \downarrow \text { bred } \\
\text { cattle }\end{array}$ & {$[\% \mathrm{hh}]$} & 13 & 27 & 13 \\
\hline Pigs & {$[\% \mathrm{hh}]$} & 20 & 33 & 13 \\
\hline \multicolumn{5}{|l|}{ Income source } \\
\hline Sell of kale & {$[\% \mathrm{hh}]$} & 47 & 53 & 7 \\
\hline Sell of wood & {$[\% \mathrm{hh}]$} & 7 & 73 & 67 \\
\hline Sell chickens & {$[\% \mathrm{hh}]$} & 20 & 33 & 13 \\
\hline $\begin{array}{l}\text { Non } \downarrow \\
\text { agricultural } \\
\text { income }\end{array}$ & {$[\%]$} & $21 \pm 18$ & $55 \pm 31$ & 35 \\
\hline
\end{tabular}

${ }^{\mathrm{a}}$ Source: Tittonell et al. (2005); ${ }^{\mathrm{b}}$ number of people; ${ }^{\mathrm{c}}$ household; ${ }^{\mathrm{d}}$ both DAP and CAN

resources. Similar patterns of resource acquisition have also been reported for the same region (Kristjanson et al. 2004; Dose 2007). Five of the original farms were subdivided (from two to six pieces) and passed on to male children reducing the cropland available for each new household. Our analysis was restricted to the original households, managing the remaining of the original farmland. Additionally, four of the households interviewed sold land between 2003 and 2013 to be able to pay for health care or education, while five bought land during the same period to increase agricultural production and to be able to pass land on to their sons without subdividing the original farm land. However, $\sim 60 \%$ of the total increase registered in cropland area was the result of changes in only two of the households interviewed (Fig. 4a), which resulted in a non-significant difference in average cropland areas per household between 2003 and 2013.

In terms of labour, in 2013, four households made arrangements to share labour with other households for agricultural activities. Additionally, a few of the interviewed households sold their own labour for agricultural activities on other farms in exchange for cash, while $94 \%$ of households hired casual labour for cropping activities, and $60 \%$ hired oxen services to prepare their land.

(iii) Changes in prices of inputs and products: During the household interviews, it was stated that there was an increased need for cash to cover household needs and to purchase farm inputs. For example, comparing the changes in the relative costs of inputs and products (reported by farmers and other key informants) showed that the price of maize for food increased more than proportionally with respect to the price for inorganic fertilizers, hybrid seeds and labour. This disproportional increase of prices suggests that the purchasing capacity decreased for households practicing small-scale subsistence farming and working off-farm to buy maize, whereas farmers producing maize for the market could benefit from the high product prices in 2013.

(iv) Better markets and infrastructure: Farmers perceived greater market opportunities through better access to information and transport and an increased demand for agricultural products such as food and firewood. Most farmers mentioned that road quality and increased availability of motorbikes had allowed them to have a better access to markets. Similarly, there was a perceived market development represented as an increased supply and demand of different products in the region such as agricultural inputs. In Shinyalu, a major market of the study area, key informants reported that agro-dealers increased from two to six shops together with an increase in the number of smaller input sellers (i.e. retailers) during market days. Related to road improvement, most farmers also mentioned the better accessibility to the area as a result of the expansion in coverage of motorcycle taxis. This was also reflected in an increase in mechanic shops at Shinyalu marketplace from 3 to 14 during the last decade. Although the electricity network also expanded into the study area, most farmers did not yet have access to it because of the high installation costs.

\section{Livelihood strategies}

Based on their own objectives and possibilities, households combined different strategies to act on and take advantage of changes in their structure, life cycle and their context. Specifically, these strategies included: increased land and labour exchange (explained in the previous section), agriculture intensification and diversification, and diversification of other income sources. In terms of agriculture intensification, most households increased frequency of cultivation (i.e. percentage of the land cultivated in a year), while using external inputs such as inorganic fertilizers and 
hybrid seeds (see also "Changes in crop management and soil condition" section). Farming activities diversified across farms, particularly those related to livestock production (Table 1). The number of households with crossbred cattle and pigs increased. On-farm income further diversified by increasing the number of households selling pigs and chickens, vegetables and firewood and timber, in response to the increasing local demand for these products. However, selling of milk decreased as a consequence of the reduction in the number of cattle partly caused by animal diseases (Fig. 4a), selling of animals for investments and eventual dowries.

In terms of income diversification, most households increased their share of non-agricultural income (Fig. 4b). In 2003, the share of off-farm income for most households represented less than half of their income. In 2013, half of the income of households was derived from off-farm activities. The tendency of increasing the share and importance of off-farm income in the rural livelihoods is common in developing countries (Ellis 2000; Barrett et al. 2001; Haggblade et al. 2010). Increases in off-farm income reflected the emergence or consolidation of economic activities such as trade of molasses and by-products, and miscellaneous shops (e.g. groceries, tailoring), as well as migration to rural centres (e.g. remittances). Some households combined several of these strategies (Fig. 4). For example, most households that increased their total cultivated area also increased the share of their income from off-farm activities such as income from own business.

Farmers mentioned that the diversification of both onand off-farm activities and income was often related to covering an increasing need for cash to cover frequent expenses such as buying food, or to cover specific household expenses such as health care, education and hired labour. This diversification was also related to an increasing local and regional demand for food, including animal products and vegetables. According to farmers, most buyers/traders of molasses by-products, milk, chickens, pigs and trees come to their farms to buy these products. These processes describe a better supply chain integration and larger dependency of the rural livelihoods and farming systems on a growing market. However, market dependency can also have detrimental effects for household income when expenses to cover food needs increase, which can result in reduced purchasing and consumption of nutritious foods, as observed in a similar region (Conelly and Chaiken 2000).

Household heads outlined diverse potential future strategies including investment in crops intensification and diversification, livestock production, and further development of their own business, and the purchase of more land (Fig. 5). Many of the selected households (65\%) were planning to diversify on-farm income by acquiring cattle to

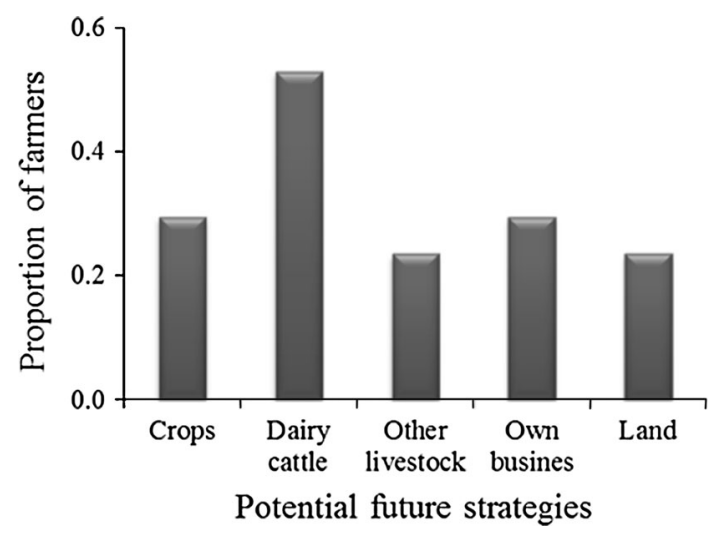

Fig. 5 Proportion of farmers preferring specific future strategies among the households interviewed in 2013

produce milk, as well as to invest on small livestock production given the increasing demand and high prices for these products. Although this contradicts the apparent trend of many households reducing cattle in the last decade, such a reduction in our small sample was only temporary, either caused by animal diseases or in order to pay for other household activities (e.g. dowries, buying land). Alternatively, some farmers were willing to invest in crop intensification or diversification (e.g. vegetables and sugar cane for local consumption), or in expanding their own business to access more frequent income. Some farmers would also invest in acquiring additional land to increase agricultural production and pass-on land to their sons to avoid land fragmentation, while five of the farms visited would be subdivided soon. Finally, although some farmers also mentioned education as a future investment option, $75 \%$ of the households are already investing in education for their children to provide them with more future opportunities, not necessarily in farming, which might affect future rural population dynamics.

\section{Changes in crop management and soil condition}

In 2013, households increased the average frequency of cultivation by almost $50 \%$ reflecting the need to increase crop production, further reducing the areas left as fallow during the short growing season, which has been an ongoing process in the area (Nambiro 2008). Households that fallowed during this season did it either to provide grazing areas for the livestock, to improve soil fertility, and/or to avoid incurring in extra labour costs given the low potential of crop returns expected during this season. Instead of crop production, these households chose to secure animal feed availability, and increase capital and labour efficiency to enhance overall farm production and well-being in 2013. This indicates how smallholder rural households deal with trade-offs, selecting where to allocate 
Table 2 Price of maize as food and relative values of major agricultural inputs with respect to the price of maize, as well as differences in value in the study area between 2005 and 2013

\begin{tabular}{lllll}
\hline Item & $2005^{\mathrm{a}}$ & 2009 & 2013 & $\begin{array}{l}\text { Difference (\%) } \\
2005-2013\end{array}$ \\
\hline Maize (KES/kg) $^{\mathrm{b}}$ & 20 & 28 & 40 & 100 \\
Daily labour $^{\mathrm{c}}$ & 5.0 & 4.3 & 3.8 & -25 \\
Animal plough & 68 & 40 & 38 & -44 \\
DAP & 105 & 100 & 95 & -10 \\
CAN & 94 & 100 & 68 & -28 \\
Farmyard manure & 2.5 & 5.3 & 7.5 & 200 \\
Seed hybrid maize & 14 & 11.4 & 9.0 & -33 \\
\hline
\end{tabular}

${ }^{a}$ Source: Tittonell et al. (2007); ${ }^{\mathrm{b}}$ prices from January to June; c average $6 \mathrm{~h}$ a day excluding food

key resources based on their own objectives and possibilities. The development and adaptation of technologies and management strategies for smallholder rural households needs to account for these objectives and major trade-offs in resource allocation.

Compared with 2003, the households interviewed in 2013 used less manure as soil amendment partly as a consequence of the reduction in the number of cattle. The number of households using market inputs such as inorganic fertilizers or maize hybrid seed increased (Table 2), particularly those combining fertilizer applications at planting (i.e. di-ammonium phosphate or DAP) and top dressing (i.e. calcium ammonium nitrate or CAN). This intensification of input use was partly supported by new institutional developments. Specifically, eight farmers mentioned that they had participated or were participating in micro-credit programmes to access and better use inputs, shared labour and related information offered by the One Acre Fund (http://www.oneacrefund.org/). Similarly, five farmers mentioned their active participation in community micro-credit and labour-sharing programmes, especially for women. This illustrates how institutions can provide relevant knowledge and key agricultural inputs that can facilitate crop intensification. Nevertheless, questions on the long-term viability of these institutional innovations and a potential competition with local traders remain open.

Changes in management did not lead to significant changes in the soil fertility indicators measured in 2003 and 2013, namely soil organic carbon (SOC), total soil $\mathrm{N}$ and available $\mathrm{P}$, in most of the fields sampled. The samples taken in 2013 exhibited SOC levels between 15 and $20 \mathrm{~g} \mathrm{~kg}^{-1}$, similar to those observed in 2003 (Fig. 6). Yet, two samples showed an increase of $5 \%$ reaching $\sim 23 \mathrm{~g} \mathrm{~kg}^{-1}$ of SOC, which remains at low levels (Waswa et al. 2013). Soil concentrations of total $\mathrm{N}$ and available $\mathrm{P}$ changed drastically for some of the selected the selected fields between both sampling periods. Some of the fields that exhibited very low levels of total $\mathrm{N}$ in 2003 $\left(<0.5 \mathrm{~g} \mathrm{~kg}^{-1}\right)$ increased their contents to average levels of between $1.8-2.3 \mathrm{~g} \mathrm{~kg}^{-1}$. Extractable $P$ values remained at very low levels, in most cases far below the $10 \mathrm{mg} \mathrm{kg}^{-1}$ cited as reference for response to fertiliser $\mathrm{P}$ in the soils of the area (Vanlauwe et al. 2006). Some fields exhibited lower available $\mathrm{P}$ levels while others, that were at very low levels in 2003 had now relatively high concentrations. Such small positive changes could be caused by the use of organic or inorganic $\mathrm{P}$ inputs during the period considered, particularly in the originally less fertile fields.

The lack of change in these soil indicators for most fields suggest that SOC, total $\mathrm{N}$ and available $\mathrm{P}$ were already at or close to their lower equilibrium concentrations in 2003 (Tittonell et al. 2005a and b) and the situation has not changed. The soil fertility gradients that were described by Tittonell et al. (2005a and b) were not observed in this sub-sample, perhaps as a result of the changes described (land fragmentation, increased fertiliser use, etc.), although conclusions cannot be drawn from the small number of observations included in this study. Although farmers mentioned that a better access and use of inorganic fertilizers had an overall positive impact on crop productivity, the variable access to manure and reduction of fallow periods indicated that current crop management would likely keep the soils impoverished. To face this process, most households are increasingly investing in external inputs to maintain or improve crop production, basing their decisions upon the market and global prices for fertilizers.

Trajectories of rural households

The trajectories of rural households in the study area are conceptually represented in Fig. 7 and specified in Annex A. The socio-economic context changed in the last decade, influencing the window of opportunity for households who act or anticipate to such changes in different ways (thresholds $P$ and $S$ ). For instance, a better link to markets influenced households' needs (e.g. for cash to pay labour and education) and opportunities (e.g. increasing local demand for feed and livestock production). Along with these changes, households combined different strategies on access to resources and adaptive capacity. Such changes can be best illustrated through examining individual storylines and household life cycles (cf. Box 1). There were four households who have stepped up/out (trajectory $a$ ). Despite temporary changes and an overall reduction in cattle numbers, three of them have increased the farm size and/or have largely increased their off-farm income and their maize food self-sufficiency in the last decade, the latter being already high in 2003. Nine households have remained in a relatively bearable situation, hanging in and 

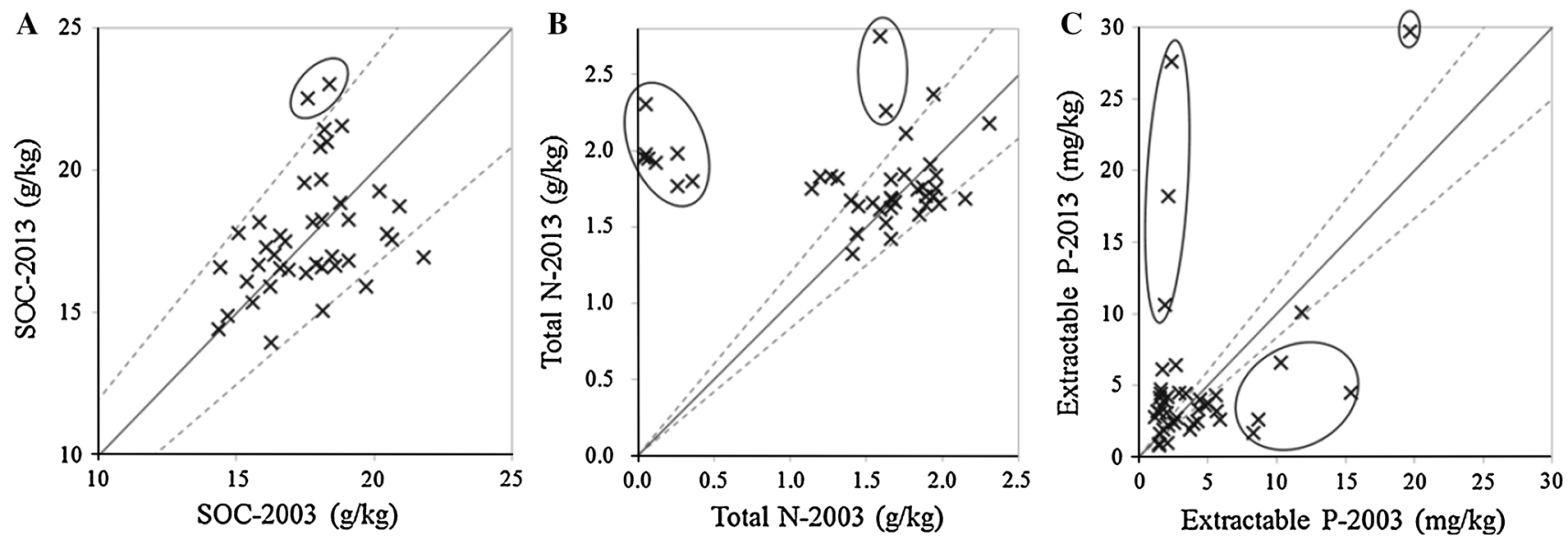

Fig. 6 Changes in soil organic carbon (a), total nitrogen (b) and available phosphorus (c) between 2003 and 2013. Solid lines represent one to one ratios between 2003 and 2013 measurements.
Dotted lines represent a margin of error of $20 \%$. Encircled points are those with substantial changes between the two study periods. Data from 2003 were previously published in Tittonell et al. (2005)

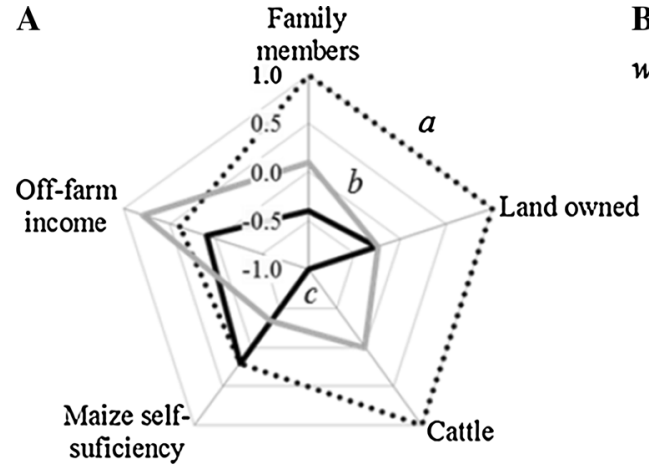

Fig. 7 Representation of major changes and trajectories of four selected households showed in a grey, black and dotted line. a Proportional changes of three households in five household indicators in 2013 based on values of 2003. The household that

reflecting a diverse range of situations of coping with changes in both drivers and household situation, which might follow different future pathways (trajectory $b$ ). These situations range from illness of the household head, the sons forming their own household and the selling of some land; starting up of a new young household head without much capital and extra labour but with different plans while renting out some land to build capital for future investments; and a household who lost their livestock and sold some land to pay the education of their children, but still owning some land and off-farm activities to make future investments. Two female-headed and relatively elder households are coping with the social-ecological context (trajectory $c$ ), with limited labour and capital to invest in their farm while reducing their maize self-sufficiency and depending on remittances of other relatives. Finally, four households have stepped out (trajectory $d$ ) either by the

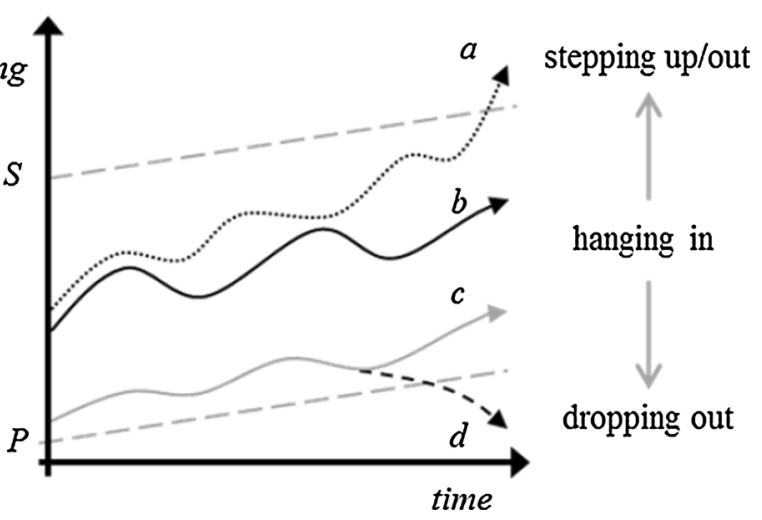

dissolved (trajectory d) is not shown. b Conceptual representation of trajectories of these households. See explanation in the text. $S$ and $P$ represent theoretical thresholds that increase because of changes in the socio-economic and biophysical context

disintegration of the household or by the selling of the land to invest in a region with cheaper land and better investment options.

The strategies that surveyed households deployed during the last decade were a combination of coping and adaptation strategies to respond to changes within the household structure, life cycle and the context. Households used coping strategies to cover their basic needs, as observed in other smallholder agroecosystems (e.g. Dorward 2009; Mushongah and Scoones 2012), by selling most of the household labour, selling and renting out land, etc. Households deploying coping mechanisms tended to be those with an already limited access to resources and who often relied on selling their labour to other households (i.e. poverty trap (Carter and Barrett 2006)), or those with better access to resources but who experienced drastic changes such as labour limitations (e.g. due to illness) and land 


\section{BOX 1 Household storylines}

Examples from individual households can be used to illustrate the different possible trajectories depicted in Fig. 7. A household that had 1.2 ha of land and 7 heads of livestock in 2003 obtained extra income through off-farm employment for a number of years, and invested part of this income in acquiring more land and livestock. Although the farmer managed to increase maize production, household self-sufficiency of maize remained similar as in 2003 due to an increase in family size (trajectory $a$ ). The head of another household, with a relatively large farm (1 ha) and 2 heads of livestock in 2003, fell ill and some of his sons got married and left the household. This affected the overall well-being of the household (trajectory $b$ ). To cope with these changes, they sold their cattle and part of the farm, while renting out some of the remaining land. They have also limited the purchase of external inputs and not planted the rest of the land during the short rainy season to fallow it given the limited labour and capital available. Still, they continued to produce Napier grass, vegetables and chickens to acquire farm income, while obtaining economic support to cover part of the health treatment. A third household had only four adults working. Part of 0.4 ha of the farm in 2003 was sold and they hardly used any external input on their crops (e.g. fertilizers, hybrid seeds). To fulfil the household requirements, two of the adults worked as daily labourers in other farms limiting their work in their own farm (trajectory $c$ ). Finally, two households dropped out of agriculture because their adult members died and their children and land went to other families (trajectory $d$ ).

reduction (e.g. due to farm fragmentation) - i.e. transitional ruptures (Wilson 2007). Households followed adaptation strategies to step up or out, improving their access to resources and livelihoods as described by Lay et al. (2008) for the region. These strategies included buying additional land, creating or enhancing their own businesses, and diversifying and intensifying agricultural production among others. The way in which households combined different adaptation strategies depended on their past trajectories and on their access to resources. A major consequence of this differentiation among households coping with or adapting to changes is the growing inequity among household in the region.

To understand the structure, diversity and dynamics of these coping mechanisms and adaptation strategies is a fundamental step towards improving the adaptation of technologies and the design development and policymaking processes to reduce vulnerability and improve future pathways for rural communities. This study describes the trajectories of a small number of households that were selected based on a farm typology delineated 10 years ago. Their small number does not allow deriving conclusive patterns of household dynamics. Yet, the observed changes operated in these households, in combination with the changes that operated at national level, allow extracting some general remarks that are supported by other studies conducted in the region. In general, despite the past and current land fragmentation processes and increasing population densities, agriculture still remains an important livelihood strategy for income, food and nutritional security. These processes are likely to continue (Lay et al. 2008), challenging further the food self-sufficiency in these highly populated regions. Although many households keep coping and adapting to support their livelihoods by migration and off-farm income, the questions remain as to what is the desired future for rural households and smallholder agriculture in this region according to the local communities, policy-makers, development actors and society in general and as to how this desired future is represented in national policies. Improving agricultural production for every household might not have a real impact in poverty alleviation and food security (Harris and Orr 2014).

Even if a policy framework is available, however, there still seems to be a lack of political willingness to implement it in order to really address the needs of the more vulnerable households and regions (Poulton and Kanyinga 2013). Specifically, policies and development programmes should be flexible and adaptive to be able to include some of these dynamics and diversity. For example, programmes could aim at improving the adaptive capacity (e.g. training), reducing risks (e.g. credits) and ensuring access to markets of household members, specifically those with more vulnerable trajectories. The highly dynamic nature of rural households revealed in this study suggests that temporal analyses needs to be included to inform policy and development (e.g. longitudinal surveys, transitional studies).

\section{Conclusions}

Improving rural livelihoods in Western Kenya is a "moving target" that needs to account for the diverse strategies that household use to act, cope and adapt to fast-changing local and regional dynamics. Limited land availability to expand farm sizes and ensure food self-sufficiency and increasing dependence on off-farm income suggest that the future of local rural livelihoods would increasingly depend on the combination of both agricultural and non-agricultural activities. The existence and prevalence of non-agricultural rural households and strategies are an important aspect to be considered in any policy or development plan for the region. The trajectories of change of the households surveyed in this study have been embedded in the interactions and dynamics of biophysical and socio-ecological drivers that prevailed in Kenya, and to some extent in the region, over the past decade. The strategies deployed by these households to act on such changes and their own life cycle changes shaped their livelihoods and farming 
systems. Population dynamics and economic growth have allowed the development of local and regional markets reflected in an increasing offer and demand for different agricultural products, household labour and land. The bestendowed households had more opportunities to adapt and step up/out, improving their level of well-being, while the poorest simply hanged-in, coping with changes and remaining in a poverty trap. This seems to have resulted in an increasing inequity in resource endowment and wellbeing among households. Although it remains challenging to quantify these trajectories and interactions given the nonlinearity and emergent properties of these social-ecological systems, the storylines of these 20 households allowed us to have a better understanding of the complexity and interactions between patterns and processes in smallholder agroecosystems. To assert whether the trajectories of these households represent a pattern for the region or not, the dynamics of livelihoods strategies should be studied among a larger population in the study area. Nevertheless, this limited study illustrates the highly dynamic and heterogeneous nature of rural livelihoods in highly populated regions. The analysis of their trajectories of change, through more frequent longitudinal surveying for instance, is essential to contextualise rural dynamics in order to design research and inform future options for more sustainable agroecosystems.

Acknowledgments The authors especially thank the farmers who kindly shared their knowledge, views and experiences for this study. We would also like to thank Dave Watson (MAIZE), Deborah Bossio (CIAT), Josephine Olwal (CIAT) and Frederick Baijukya (CIAT) for their support in the implementation of this project. This study was funded by MAIZE and WHEAT CGIAR Research Programmes.

Open Access This article is distributed under the terms of the Creative Commons Attribution License which permits any use, distribution, and reproduction in any medium, provided the original author(s) and the source are credited.

\section{Appendix}

Table 3 Description of the structure of the selected households in 2003 and their major changes between 2003-2013

\begin{tabular}{|c|c|c|c|c|c|c|c|c|c|c|c|c|}
\hline \multirow[t]{2}{*}{ ID } & \multicolumn{5}{|c|}{ Structure 2003} & \multicolumn{6}{|c|}{ Changes $2003 \downarrow 2013$} & \multirow{2}{*}{$\begin{array}{l}\text { Potential } \\
\text { trajectory }^{\text {a }}\end{array}$} \\
\hline & $\begin{array}{l}\text { hh size } \\
\text { (people) }\end{array}$ & $\begin{array}{l}\text { Farm } \\
\text { size } \\
\text { (ha) }\end{array}$ & $\begin{array}{l}\text { Cattle } \\
\text { (No.) }\end{array}$ & $\begin{array}{l}\text { Off-farm } \\
\text { income }(\%)\end{array}$ & $\begin{array}{l}\text { Maize self- } \\
\text { sufficiency } \\
\text { (months) }\end{array}$ & Continue & $\begin{array}{l}\text { hh } \\
\text { size }\end{array}$ & $\begin{array}{l}\text { Farm } \\
\text { size }\end{array}$ & Cattle & $\begin{array}{l}\text { Off-farm } \\
\text { income }\end{array}$ & $\begin{array}{l}\text { Maize self- } \\
\text { sufficiency }\end{array}$ & \\
\hline 1 & 4 & 1.18 & 7 & 0 & 10 & + & + & + & + & + & + & a \\
\hline 2 & 10 & 0.37 & 2 & 40 & 9 & + & + & $=$ & - & + & + & $\mathrm{a}$ \\
\hline 3 & 6 & 0.37 & 8 & 30 & 12 & + & - & + & - & - & $=$ & a \\
\hline 4 & 9 & 0.23 & 1 & 30 & 10 & + & - & + & - & + & + & a \\
\hline 5 & 9 & 1.21 & 5 & 0 & 12 & + & $=$ & - & - & + & $=$ & $\mathrm{b}$ \\
\hline 6 & 5 & 1.01 & 2 & 0 & 10 & + & - & - & - & + & + & $\mathrm{b}$ \\
\hline 7 & 14 & 0.74 & 5 & 30 & 8 & + & - & + & - & + & $=$ & $\mathrm{b}$ \\
\hline 8 & 2 & 0.28 & 6 & 0 & 8 & + & + & - & - & + & + & $\mathrm{b}$ \\
\hline 9 & 6 & 0.28 & 2 & 60 & 10 & + & - & $=$ & $=$ & + & - & $\mathrm{b}$ \\
\hline 10 & 7 & 0.28 & 4 & 0 & 9.5 & + & - & $=$ & - & + & - & $\mathrm{b}$ \\
\hline 11 & 6 & 0.23 & 8 & 20 & 9 & + & - & - & - & + & + & $\mathrm{b}$ \\
\hline 12 & 8 & 0.20 & 5 & 20 & 12 & + & - & + & - & - & - & $\mathrm{b}$ \\
\hline 13 & 7 & 0.18 & 3 & 40 & 7 & + & - & - & - & $=$ & - & $\mathrm{b}$ \\
\hline 14 & 4 & 0.46 & 1 & 20 & 8 & + & + & - & $=$ & + & - & $\mathrm{c}$ \\
\hline 15 & 10 & 0.44 & 0 & 20 & 9 & + & + & - & n.a & + & - & c \\
\hline 16 & 1 & 1.10 & 0 & 20 & 10 & - & $\mathrm{n} . \mathrm{a}$ & n.a & $\mathrm{n} . \mathrm{a}$ & n.a & n.a & d \\
\hline 17 & 2 & 0.23 & 0 & 50 & 9 & - & n.a & n.a & n.a & n.a & n.a & $\mathrm{d}$ \\
\hline 18 & 4 & 0.18 & 1 & 40 & 4 & - & $\mathrm{n} . \mathrm{a}$ & n.a & n.a & n.a & n.a & $\mathrm{d}$ \\
\hline 19 & 7 & 0.00 & 0 & 30 & 2 & - & n.a & n.a & n.a & n.a & n.a & d \\
\hline
\end{tabular}

n.a Not applicable

${ }^{a}$ Related to Fig. 7 


\section{References}

Anderson J, Ingram JSI (1993) Tropical soil biology and fertility: a handbook of methods. CAB International, Wallingford

Barrett CB, Reardon T, Webb P (2001) Nonfarm income diversification and household livelihood strategies in rural Africa: concepts, dynamics, and policy implications. Food Policy 26:315-331. doi:10.1016/S0306-9192(01)00014-8

Becker E, Jahn T (2001) Social-ecological research-conceptual framework for a new funding policy: synopsis of the report for the German Federal Ministry of Education and Research. Nat Sci Soc 9:73-77

Carter MR, Barrett CB (2006) The economics of poverty traps and persistent poverty: an asset-based approach. J Dev Stud 42:178-199. doi:10.1080/00220380500405261

Conelly WT, Chaiken M (2000) Intensive farming, agro-diversity, and food security under conditions of extreme population pressure in Western Kenya. Hum Ecol 28:19-51. doi:10.1023/ A: 1007075621007

Conway GR (1987) The properties of agroecosystems. Agric Syst 24:95-117. doi:10.1016/0308-521X(87)90056-4

Crowley E, Carter S (2000) Agrarian change and the changing relationships between toil and soil in Maragoli, Western Kenya (1900-1994). Hum Ecol 28:383-414. doi:10.1023/A: 1007005514841

Dorward A (2009) Integrating contested aspirations, processes and policy: development as hanging in, stepping up and stepping out. Dev Policy Rev 27:131-146. doi:10.1111/j.1467-7679.2009. 00439.x

Dorward A, Anderson S, Bernal YN, Vera ES, Rushton J, Pattison J, Paz R (2009) Hanging in, stepping up and stepping out: livelihood aspirations and strategies of the poor. Dev Pract 19:240-247. doi:10.1080/09614520802689535

Dose H (2007) Securing household income among small-scale farmers in Kakamega District: possibilities and limitations of diversification. GIGA Working Paper No. 41, Leibniz. Available at SRN: http://dx.doi.org/10.2139/ssrn.978168

Ellis F (2000) The determinants of rural livelihood diversification in developing countries. J Agric Econ 51:289-302. doi:10.1111/j. 1477-9552.2000.tb01229.x

Enfors E (2013) Social-ecological traps and transformations in dryland agro-ecosystems: using water system innovations to change the trajectory of development. Glob Environ Change 23:51-60. doi:10.1016/j.gloenvcha.2012.10.007

Geels FW, Schot J (2007) Typology of sociotechnical transition pathways. Res Policy 36:399-417. doi:10.1016/j.respol.2007.01.003

Haggblade S, Hazell P, Reardon T (2010) The rural non-farm economy: prospects for growth and poverty reduction. World Dev 38:1429-1441. doi:10.1016/j.worlddev.2009.06.008

Harris D, Orr A (2014) Is rainfed agriculture really a pathway from poverty? Agric Syst 123:84-96. doi:10.1016/j.agsy.2013.09.005

Jaetzold R, Schmidt H, Hornetz B, Shisanya C (2007) Farm management handbook of Kenya Vol II: natural conditions and farm management information, 2nd edn. Kenya Ministry of Agriculture, Nairobi

Jayne TS, Muyanga M (2012) Land constraints in Kenya's densely populated rural areas: implications for food policy and institutional reform. Food Secur 4:399-421. doi:10.1007/s12571-0120174-3

Kandij ST (2006) Drought in Kenya: climatic, economic and sociopolitical factors. New Standpoints November-December, 17-23. Available: http://www.worldagroforestry.org/downloads/publica tions/PDFs/NL06291.pdf

Keating BA, Carberry PS, Bindraban PS, Asseng S, Meinke H, Dixon J (2010) Eco-efficient agriculture: concepts, challenges, and opportunities. Crop Sci 50:109-119. doi:10.2135/cropsci2009. 10.0594

Kenya National Bureau of Statistics (KNBS) (2000) 1999 Kenya population and housing census. Nairobi

Kenya National Bureau of Statistics (KNBS) (2010) The 2009 Kenya population and housing census. Nairobi

Kenya National Bureau of Statistics (KNBS) (2012) Economic survey 2012: highlights. Nairobi

Kristjanson P, Krishna A, Radeny M, Nindo W (2004) Pathways out of poverty in Western Kenya and the role of livestock. PPLPI Working paper 14. Nairobi

Lambin EF, Geist H, Rindfuss RR (2006) Introduction: local processes with global impacts. In: Lambin EF, Geist H (eds) Land-use and land-cover change: local processes and global impacts. Springer, Berlin, pp 1-8

Lay J, Mahmoud TO, M'Mukaria GM (2008) Few opportunities, much desperation: the dichotomy of non-agricultural activities and inequality in Western Kenya. World Dev 36:2713-2732. doi:10.1016/j.worlddev.2007.12.003

Mushongah J, Scoones I (2012) Livelihood change in rural Zimbabwe over 20 Years. J Dev Stud 48:1241-1257. doi:10.1080/ 00220388.2012 .671474

Nambiro E (2008) Trends in land use and agricultural intensification in Kakamega, Western Kenya. PhD thesis, Bonn University, Bonn, p 132

Poulton C, Kanyinga K (2013) The politics of revitalising agriculture in Kenya. The Future Agricultures Consortium. FAC Working paper 59, Brighton

Pretty JN (1997) The sustainable intensification of agriculture. Nat Resour Forum 21:247-256. doi:10.1111/j.1477-8947.1997.tb00699.x

Pretty JN (2008) Agricultural sustainability: concepts, principles and evidence. Philos Trans R Soc Lond B Biol Sci 363:447-465. doi:10.1098/rstb.2007.2163

Raut N, Sitaula BK, Aune JB, Bajracharya RM (2011) Evolution and future direction of intensified agriculture in the central mid-hills of Nepal. Int J Agric Sustain 9:537-550. doi:10.1080/14735903. 2011.609648

Reardon T, Barrett C, Kelly V, Savadogo K (1999) Policy reforms and sustainable agricultural intensification in Africa. Dev Policy Rev 17:375-395. doi:10.1111/1467-7679.00093

Republic of Kenya (2012) Kenya post-disaster needs assessment 2008-2011 drought. EU, UN, and World Bank, Nairobi

Rindfuss RR, Entwisle B, Walsh SJ, An L, Badenoch N, Brown DG, Deadman P, Evans TP, Fox J, Geoghegan J, Gutmann M, Kelly M, Linderman M, Liu J, Malanson GP, Mena CF, Messina JP, Moran EF, Parker DC, Parton W, Prasartkul P, Robinson DT, Sawangdee Y, Vanwey LK, Verburg PH (2008) Land use change: complexity and comparisons. J Land Use Sci 3:1-10. doi:10.1080/17474230802047955

Ryschawy J, Choisis N, Choisis JP, Gibon A (2013) Paths to last in mixed crop-livestock farming: lessons from an assessment of farm trajectories of change. Animal 7:673-681

Safaricom (2011) M-PESA customer and agent numbers. Nairobi

Scoones I, Wolmer W (2000) Pathways of change: crops, livestock and livelihoods in Africa: lessons from Ethiopia. Mali and Zimbabwe, UK

Speelman EN, Groot JCJ, García-Barrios LE, Kok K, van Keulen H, Tittonell P (2014) From coping to adaptation-trajectories of change in land use management and social organization in a biosphere reserve community, Mexico. Land Use Policy 41:31-44. doi:10.1016/j.landusepol.2014.04.014

Tarawali S, Herrero M, Descheemaeker K, Grings EBlümmel M (2011) Pathways for sustainable development of mixed crop livestock systems: taking a livestock and pro-poor approach. Livest Sci 139:11-21. doi:10.1016/j.livsci.2011.03.003 
Tittonell P (2008) Msimu wa kupanda: targeting resources within diverse, heterogeneous and dynamic farming systems of East Africa. $\mathrm{PhD}$ thesis Wageningen University, Wageningen, p 320

Tittonell P (2013) Livelihood strategies, resilience and transformability in African agroecosystems. Agric Syst 126:3-14. doi:10. 1016/j.agsy.2013.10.010

Tittonell P, Giller KE (2013) When yield gaps are poverty traps: the paradigm of ecological intensification in African smallholder agriculture. Field Crop Res 143:76-90. doi:10.1016/j.fcr.2012. 10.007

Tittonell P, Vanlauwe B, Leffelaar PA, Rowe EC, Giller KE (2005a) Exploring diversity in soil fertility management of smallholder farms in western Kenya: I. Heterogeneity at region and farm scale. Agric Ecosyst Environ 110:149-165. doi:10.1016/j.agee. 2005.04.001

Tittonell P, Vanlauwe B, Leffelaar PA, Shepherd KD, Giller KE (2005b) Exploring diversity in soil fertility management of smallholder farms in western Kenya: II. Within-farm variability in resource allocation, nutrient flows and soil fertility status. Agric Ecosyst Environ 110:166-184. doi:10.1016/j.agee.2005. 04.003

Tittonell P, van Wijk MT, Rufino MC, Vrugt JA, Giller KE (2007) Analysing trade-offs in resource and labour allocation by smallholder farmers using inverse modelling techniques: a case-study from Kakamega district, western Kenya. Agric Syst 95:76-95. doi:10.1016/j.agsy.2007.04.002

Tittonell P, Shepherd KD, Vanlauwe B, Giller KE (2008) Unravelling the effects of soil and crop management on maize productivity in smallholder agricultural systems of western Kenya-an application of classification and regression tree analysis. Agric Ecosyst Environ 123:137-150. doi:10.1016/j.agee.2007.05.005

Tittonell P, Muriuki A, Shepherd KD, Mugendi D, Kaizzi KC, Okeyo J, Verchot L, Coe R, Vanlauwe B (2010) The diversity of rural livelihoods and their influence on soil fertility in agricultural systems of East Africa-a typology of smallholder farms. Agric Syst 103:83-97. doi:10.1016/j.agsy.2009.10.001

UN (2011) World population prospects: the 2010 revision. Department of Economic and Social Affairs, Population Division, New York

Vanlauwe B, Tittonell P, Mukalama J (2006) Within-farm soil fertility gradients affect response of maize to fertiliser application in western Kenya. Nutr Cycl Agroecosystems 76:171-182. doi:10.1007/s10705-005-8314-1

Waswa BS, Vlek PLG, Tamene LD, Okoth P, Mbakaya D, Zingore S (2013) Evaluating indicators of land degradation in smallholder farming systems of western Kenya. Geoderma 195196:192-200. doi:10.1016/j.geoderma.2012.11.007

World Health Organization (WHO) (2012) Motorcycle-related road traffic crashes Kenya facts and figures. Nairobi, p 5. Available: http://www.who.int/violence_injury_prevention/road_traffic/ countrywork/factsheet_kenya.pdf

Wilson GA (2007) Multifunctional agriculture: a transition theory perspective. Cromwell Press, Trowbridge

Wilson GA (2008) From 'weak' to 'strong' multifunctionality: conceptualising farm-level multifunctional transitional pathways. J Rural Stud 24:367-383. doi:10.1016/j.jrurstud.2007.12. 010

World Bank (2013) World development indicators [WWW Document]. http://databank.worldbank.org/

Zimmerer K (2007) Agriculture, livelihoods, and globalization: the analysis of new trajectories (and avoidance of just-so stories) of human-environment change and conservation. Agric Human Values 24:9-16. doi:10.1007/s10460-006-9028-y

Zimmerer KS (2013) The compatibility of agricultural intensification in a global hotspot of smallholder agrobiodiversity (Bolivia). Proc Natl Acad Sci 110:2769-2774. doi:10.1073/pnas. 121629411 